\title{
The Effect of Metacognitive Strategies on Prospective Teachers' Metacognitive Awareness and Self Efficacy Belief*
}

\author{
Hatice Yıldız ${ }^{1}$, Mustafa Akdağ \\ ${ }^{1}$ Education Faculty, Department of Educational Sciences, Cumhuriyet University, Sivas, Turkey \\ ${ }^{2}$ Education Faculty, Department of Educational Sciences, Inonu University, Malatya, Turkey \\ Correspondence: Hatice Y1ldı, Education Faculty, Department of Educational Sciences, Cumhuriyet University, Sivas, \\ Turkey.
}

Received: September 19, 2017

doi:10.11114/jets.v5i12.2662
Accepted: November 6, $2017 \quad$ Online Published: November 13, 2017

URL: https://doi.org/10.11114/jets.v5i12.2662

\begin{abstract}
The purpose of the research study was to investigate the effects of the metacognitive strategies used in the course Science and Technology Instruction-II on prospective teachers' metacognitive awareness, science teaching self efficacy belief and teacher self efficacy belief. The research group was composed of 87 third grade students from the Primary Education Department at the Faculty of Education at Cumhuriyet University in Sivas, Turkey. Experimental method with pre-test and post-test control group was used in the study. Metacognitive Awareness Inventory, Science Teaching Efficacy Beliefs Inventory-B (STEBI-B) and Teacher Self Efficacy Beliefs Inventory were utilized as pre-test and post-test. Journals and metacognitive questions were used in experimental group training. The research findings indicated that metacognitive strategies increased the prospective teachers' metacognitive awareness and teacher self efficacy belief but they did not increase students' science teaching self efficacy belief so much as to constitute a significant difference between the pre-test.
\end{abstract}

Keywords: metacognition, metacognitive strategies, metacognitive awareness, science teaching efficacy beliefs, teacher self efficacy belief, prospective teachers

\section{Introduction}

Alongside with the developments in the information and technology, the change in psychology theories, research conducted in 1960s and the shift from behavioral approach to cognitive approach made it necessary to reconsider concepts such as human learning, motivation and success. Cognitive theories directed people's attention from environmental variables to learner features such as how learners code, process, store and organize the information. Curricula based on constructivist teaching approach were implemented at primary school level as of 2005 in Turkey with the aim of turning these cognitive theories into practice in teaching environment. These programs attached importance to providing students with metacognitive skills in order to develop their learning. Similarly, National Academy of Sciences (NAS 2000) carried out studies for the development of children's learning and determined three important principles as follows: 1. Making students think about the world's order, 2. Developing deep content knowledge and understanding, and 3. Teaching students metacognitive skills in order for them to determine the learning objectives and monitor their level of achieving these objectives (as cited in Erskine, 2009). In this level of learning called metacognition, it is aimed to provide students with skills such as monitoring and observing their own cognitive activities, and attaining self-control.

Metacognition is "the knowledge of the person about his/her own cognitive processes and the usage of this knowledge to control the cognitive processes" (Flavell, 1985). First studies on metacognition were revealed as a result of the research conducted by Flavell on the intelligence of the children (Williams \& Atkins, 2009). Although the word metacognition had not been used commonly till then/before, it was asserted that it reflected the individual's opinion. Piaget focused on how the individual knew what he/she knew and concentrated on the individual's opinions in the early

\footnotetext{
*This paper has been produced as part of the doctoral dissertation entitled "The Effects of Metacognitive Strategies on Prospective Teachers' Metacognitive Awareness and Self Efficacy Beliefs" prepared by first author under the supervision of second author at Educational Sciences Institute of Inonu University.
} 
studies he conducted in relation to the cognitive development and individual information theory (Steinbach, 2008). Jean Piaget and Lev Vygotsky defined the importance of metacognition in cognitive development. Piaget explained the processes used by children while completing a task and their abilities of expressing the ways in which they were aware of their opinions in a research conducted on children between the ages 7 and 11. Piaget named this awareness which corresponded to the concept of metacognition as "perception awareness". Later, Vygotsky named these opinions as the "inner voice" of the child or expressing the inner opinions as a way of giving something a meaning in his research. Verbal expression of the inner opinions does not only help the student learn, but also points at the awareness of learning process (two important aspects of metacognition which are defined today) (Darling-Hammond, Austin, Cheung \& Martin, 2003).

Various definitions are introduced in the literature regarding metacognition. For instance, Jacobs and Paris (1987, p. 258) defined metacognition as "any information about the cognitive status or processes that can be shared among individuals", while Kapa (2001) as "mental operations that direct the cognitive tasks of the individual and supports the conceptualization of learning". For Hacker (1998, p. 11), metacognition can be defined as "information about the individual's knowledge, processes, cognitive and emotional statuses" and "purposeful monitoring and regulation of the individual's knowledge, processes, cognitive and emotional statuses". Considering these definitions, it is possible to summarize metacognition as the individual's knowledge about his cognitive processes and ability to regulate these processes.

For more than the past two decades, psychologists and educators have admitted that metacognition has a great power in explaining and defining the learning process and it has a central importance in successful learning (Öz, 2005). Metacognition can be developed using diverse strategies in the learning environment. In this regard, Costa (1984) suggested the following strategies: strategy planning, asking questions, conscious selections, assessment with multiple criteria, explaining the opinions of students with other words or reflecting them back, defining student behaviors, explaining student terms, acting and analogy, keeping a journal and being a model. In addition to Costa's strategies, the following metacognition development strategies were also suggested: determining "what is and is not known", metacognitive guiding (directing), PQ4R (previewing, questioning, reading, reflecting, reciting and reviewing), mutual teaching and schematic organizers. In this research, strategies of questioning and keeping a journal were used from the strategies suggested by Costa (1984). Questioning strategy facilitates students' perception; it is noticed by taking frequent breaks whether they know the case and can match it with their knowledge, and it helps them think about different examples. Then, the students decide on how the factors that prevent their learning can be eliminated. All these increase the awareness of the students and provide a conscious control over their own learning. Keeping a journal enables students to synthesize the opinions or actions and turn them into symbolic expressions. Recording the opinions enables reviewing the previous understanding, comparison of the changes in this understanding, showing strategic thinking and the decision-making process and remembering successes and failures (Costa, 1984).

In the world, which is changing continuously and technologically, it is also difficult to predict which information will be necessary for the future. Besides it is impossible to obtain the available information for all the individuals. Therefore, the call for including the metacognition in the curriculum while developing the teaching curricula seems reasonable. Gunstone and Northfield developed this view and suggested that teaching of metacognition must have a central importance in teacher education (Noushad, 2008). Because expectations of the society and the era have also diversified the roles and responsibilities of the teachers.

Self-efficacy is the belief that an individual organizes the activities necessary to demonstrate a certain performance and the capacity to exercise them (Bandura, 1995). The self-efficacy perception, whether true or false, influences the individual's preferences for action and environmental regulation. People are afraid to do things that exceed their ability to achieve, on the contrary they do things confidently they believe they can do (Bandura, 1982). At the same time self-efficacy belief affects individuals' thinking and emotional reactions. People with low self-efficiency believe that things are really harder. According to Bandura (1997), those who doubt their own competence in a certain area escape from any difficult task in this area. They have difficulty motivating themselves and they quickly give up in the face of small difficulties. At the same time, these people are very difficult to motivate themselves again after failure. On the contrary, those with positive self-efficacy beliefs perceive diffucult tasks as situations that can be achieved, they do not perceive them as a threat. These people set compelling goals for themselves and make every effort to achieve these goals. They make an effort in the work they do and they aim to achieve success by increasing this effort in the obstacles they face.

Teacher self-efficacy belief, expressing beliefs about professional competences of teachers, can be defined as a belief in the ability of a teacher to acquire the desired products, such as interest and learning, even for the less motivated and difficult students (Tschannen-Moran \& Woolfolk-Hoy, 1998). Science teaching efficacy belief, which is a special area of academic self-efficacy, can be defined as teachers' judges about their ability to teach science effectively and 
efficiently and to improve the success of the student (Akbaş \& Çelikkaleli, 2006). Teachers' knowledge and science teaching self-efficacy beliefs play an important role in the quality of science learning. However, studies conducted in the field of science education reveal that the knowledge levels of teachers and prospective teachers are not sufficient. In addition, teachers' self-efficacy beliefs about science education play an important role in the realization of effective science teaching (Kiremit \& Gökler, 2010).

Science teaching self-efficacy as a factor of teacher self-efficacy has great influence and prominence in the classroom environment. Since self-efficacy is an individual's perception of self, well-trained prospective teachers' science self-efficacy perceptions should be high. If the self-efficacy level of prospective teachers graduated from the primary school teacher's degree program is thought to be influenced by the applied curriculum, it is important to determine the effectiveness of the curriculums supported by contemporary learning approaches in practice. In this study, it is aimed to investigate the effects of metacognitive strategies on prospective teachers' metacognitive awareness, science teaching self-efficacy and teacher self-efficacy beliefs. The following research questions guided this research study:

1. Is there a meaningful difference between the experimental group students' and the control group students' metacognitive awareness?

2. Is there a meaningful difference between the experimental group students' and the control group students' science teaching self-efficacy perceptions?

3. Is there a meaningful difference between the experimental group students' and the control group students' teacher self efficacy belief?

\section{Method}

\subsection{Research Design}

Quantitative research method was used in this research. The data were collected by experimental method. Two groups experimental method with pre test-post test design was used to determine whether the metacognitive strategies have any effect on the prospective teachers' metacognitive awareness, science teaching self-efficacy beliefs and teacher self-efficacy beliefs. In this case, a measurement is made for the dependent variable both before and after the experimental study.

\subsection{Study Group}

The research was conducted on 87 prospective teachers who studied in Elementary Education Department of Cumhuriyet University, Faculty of Education. The experiment group consists of 44 and the control group of 43 students. It was determined before the experiment that the student numbers, general grade-point averages $\left(\mathrm{t}_{(85)}=.36, \mathrm{p}>.05\right)$, metacognitive awareness levels $\left(\mathrm{t}_{(85)}=.74, \mathrm{p}>.05\right)$, science teaching efficacy belief $\left(\mathrm{t}_{(85)}=.89, \mathrm{p}>.05\right)$ and teacher efficacy belief $(\mathrm{U}=.89, \mathrm{p}>.05)$ of the groups were equal to each other.

\subsection{Data Collection Tools}

\subsubsection{Metacognitive Awareness Inventory}

In order to determine students' metacognitive awareness levels, the Metacognitive Awareness Inventory (MAI), which was developed by Schraw and Dennison (1994) and adapted to Turkish, was used (Akın et al., 2007).

MAI is an inventory consisting of 52 items at a 5-point likert type. Score interval of the scale is 52-60. Turkish adaptation of the inventory was carried out with university students. Accordingly, reliability coefficient, which was obtained with the Cronbach alpha value and the test-retest method, was calculated as 0.95 during the investigation of the scale's reliability. As a result of the linguistic equivalence study, the correlation coefficient between the original and adapted forms of the scale was found as .89 and the concurrent validity coefficient as 0.93 .

The results of the Confirmatory Factor Analysis (CFA), which was conducted with the final data of this study for the confirmation of the MAI's two-factor structure, showed that the goodness of fit indexes $\left(\chi^{2} / \mathrm{sd}=1.61\right.$; RMSEA $=.07$; $\mathrm{RMR}=.08)$ of the two-factor model were at acceptable levels. In other words, two-factor structure of the scale was confirmed. The Cronbach Alpha reliability coefficients, which were calculated for the factors of the scale, were found as .74 for the factor of the cognition knowledge, as .86 for the factor of the cognition regulation and .89 for the general scale.

\subsubsection{Science Teaching Efficacy Belief Inventory (STEBI-B)}

Science Teaching Efficacy Belief Inventory (STEBI-B) was developed by Riggs and Enochs (1989) with the aim of measuring the prospective teachers' science teaching self-efficacy beliefs and it was adapted into Turkish by Özkan, Tekkaya and Çakıroğlu (2002). STEBI-B consists of 23 items and two factors as Personal Science Teaching Efficacy Belief and Science Teaching Outcome Expectancy. The Cronbach Alpha realibility coefficient for Personal Science 
Teaching Efficacy Belief was found .76 and for Science Teaching Outcome Expectancy was found .90 by Riggs and Enochs (1989). Özkan, Tekkaya and Çakıroğlu (2002) found the Cronbach Alpha realibility coefficient .79 for Personal Science Teaching Efficacy Belief and .86 for Science Teaching Outcome Expectancy.

Confirmatory Factor Analysis (CFA) was conducted to confirm the two-factor structure of STEBI-B with the final data of this study. CFA results showed that the two-factor model goodness-of-fit indexes were acceptable $\left(\chi^{2} / \mathrm{sd}=1,43\right.$; $\mathrm{RMSEA}=.05 ; \mathrm{RMR}=.07)$. The reliability coefficients was calculated for the factors of the scale in this study. The Cronbach Alpha reliability coefficients was found as .82 for Personal Science Teaching Efficacy Belief and .76 for Science Teaching Outcome Expectancy and .73 for overall STEBI-B.

\subsubsection{Teacher Efficacy Scale}

Teacher Efficacy Scale (TES) was developed by Tschannen-Moran and Hoy (2001) to determine self-efficacy perceptions of teacher and prospective teachers. The adaptation to the Turkish version and validity-reliability study of the scale was performed by Çapa, Çakıroğlu and Sarıkaya (2005). TES consists of 24 items and three factors (Efficacy for student engagement, efficacy for instructional strategies and efficacy for classroom management).

Çapa, Çakıroğlu and Sarıkaya (2005) determined that all the items have acceptable fit indexes as a result of the Rasch analysis in the adaptation study with the participation of 628 prospective teachers. As a result of confirmatory factor analysis, there were found goodness-of-fit indexes supporting the three-factor structure proposed by Tschannen-Moran and Hoy (2001). Çapa, Çakıroğlu and Sarıkaya (2005) found the Cronbach Alpha realibility coefficient .82 for Efficacy for Student Engagement, .86 for Efficacy for Instructional Strategies and .84 for Efficacy for Classroom Management and .93 for overall TES.

Confirmatory Factor Analysis (CFA) was conducted to confirm the three-factor structure of TES with the final data of this study. CFA results showed that the three-factor model goodness-of-fit indexes were acceptable $\left(\chi^{2} / \mathrm{sd}=2,17\right.$; $\mathrm{RMSEA}=.12$; SRMR $=.08$ ). The reliability coefficients was calculated for the factors of the scale in this study. The Cronbach Alpha reliability coefficients was found as .87 for Efficacy for Student Engagement, .90 for Efficacy for Instructional Strategies, .90 for Efficacy for Classroom Management and .96 for overall TES.

\subsection{Data Collection}

In this research, experimental investigations were conducted within the scope of Science and Technology Teaching-II included in the undergraduate program of the Classroom Teaching Department. While teaching was performed on the basis of metacognitive strategy in the experiment group, metacognitive strategy was not used in the control group. In the research, MAI, STEBI-B and TES was applied to both groups as the pre-test before the experimental investigation and the post-test after the experimental investigation. The courses in both the experiment and control groups were given by the researcher. Courses were given three hours a week and continued 10 weeks in total. In this period, metacognitive education was given to the experiment group after the application of the pre-test. Lessons were taught according to the same plan in experiment and control groups and same activities were performed in relation to the subject. Additionally, the experiment group was asked to keep a structured journal at the beginning and end of the course, and metacognitive questions were included in some activities.

\subsection{Data Analysis}

While analyzing the quantitative data of the research, parametric tests were used when the data were normal, and nonparametric tests were used when the data were not normal.

Independent sample t-test was applied to compare the pre-test and post-test scores of the experiment and control groups, and dependent sample t-test was performed to compare the pre-test and post-test scores within the experimental and control group itself. Also Wilcoxon signed rank test was applied for TES to compare the pre-test and post-test scores of the experiment and control groups itself. Significance level was considered as .05 during comparisons.

\section{Results}

\subsection{Comparison of the Post-test Scores Related to the Metacognitive Awareness of the Students in Experiment and Control Groups}

The results of the independent sample t-test, which was conducted to examine whether there was any significant difference between the MAI post-test scores of the students in experiment and control groups at the end of the experimental investigation, were given in Table 1. 
Table 1. Prospective teachers' MAI post-test scores results

\begin{tabular}{|c|c|c|c|c|c|c|c|c|}
\hline & & Group & $\mathrm{N}$ & $X$ & $\mathrm{~S}$ & $\mathrm{Sd}$ & $\mathrm{t}$ & $p$ \\
\hline \multirow{2}{*}{$\begin{array}{l}\text { Knowledge } \\
\text { cognition }\end{array}$} & \multirow[t]{2}{*}{ of } & Experiment & 44 & 66.6 & 6.2 & \multirow{2}{*}{85} & \multirow{2}{*}{4.03} & \multirow{2}{*}{$.000 *$} \\
\hline & & Control & 43 & 61.2 & 6.2 & & & \\
\hline \multirow{2}{*}{$\begin{array}{l}\text { Regulation } \\
\text { cognition }\end{array}$} & \multirow[t]{2}{*}{ of } & Experiment & 44 & 131.4 & 15.7 & \multirow{2}{*}{85} & \multirow{2}{*}{2.68} & \multirow{2}{*}{$.009 *$} \\
\hline & & Control & 43 & 123.3 & 11.9 & & & \\
\hline \multirow{2}{*}{ MAI } & & Experiment & 44 & 197.9 & 21.2 & \multirow{2}{*}{85} & \multirow{2}{*}{3.25} & \multirow{2}{*}{$.002 *$} \\
\hline & & Control & 43 & 184.5 & 17.2 & & & \\
\hline
\end{tabular}

$* p<.0 \overline{5}$

It was seen in Table 1 that post-test scores of Knowledge of Cognition, Regulation of Cognition and overall MAI of the prospective teachers were higher in the experiment group compared to the control group. As a result of the t-test, statistically significant differences were found between the groups' post-test scores related to the overall $\mathrm{MAI}\left[\mathrm{t}_{(85)}=3.25\right.$, $p<.05]$. Moreover, significant differences were also observed between the post-test scores of the groups at the "Knowledge of Cognition" and "Regulation of Cognition" factors of the MAI. This indicated that the applied experimental investigation increased the metacognitive awareness of the prospective teachers in the experiment group.

The data about the metacognitive awareness obtained from the pre-test and post-test performed in different groups was presented in Table 2.

Table 2. Means, Standart Deviations and Comparisons Control and Experimental Group Metacognitive Awareness by Pre and Post Test

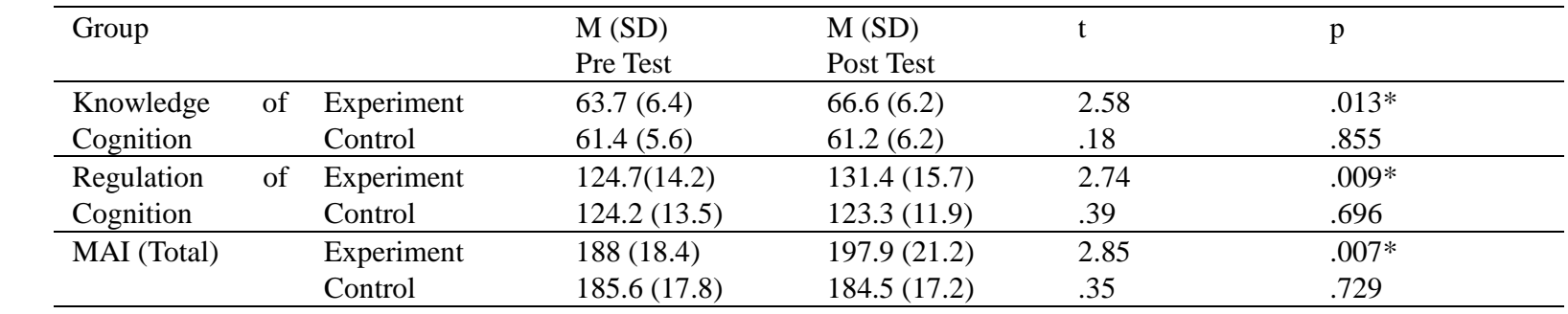

$* \mathrm{p}<.05$

As shown in Table 2, it was understood that the metacognitive awareness levels of the experiment group students generally enhanced in the post-test. It was seen as a result of the t-test applied in the dependent groups that there were statistically significant differences between the pre-test and post-test means of knowledge of cognition, regulation of cognition components and overall of the MAI $\left(\mathrm{t}_{(43)}=2.85, p=.05\right)$. These results showed that metacognitive strategies increased the awareness of the prospective teachers in the experiment group with regard to the overall and factors of the MAI. However, a decrease was observed in the post-test means of the control group. But no significant difference was found between the pre-test and post-test means of control group. It was inferred from these findings that no change occured in the metacognitive awareness of the students when metacognitive strategy was not used.

\subsection{Comparison of the Post-Test Scores Related to the Science Teaching Efficacy Beliefs (STEBI-B) of the Students in} Experiment and Control Groups

The results of the independent sample t-test, which was conducted to examine whether there were any significant difference between the STEBI-B post-test scores of the students in experiment and control groups at the end of the experimental investigation, were given in Table 3.

Table 3. Prospective teachers' STEBI-B post-test scores results

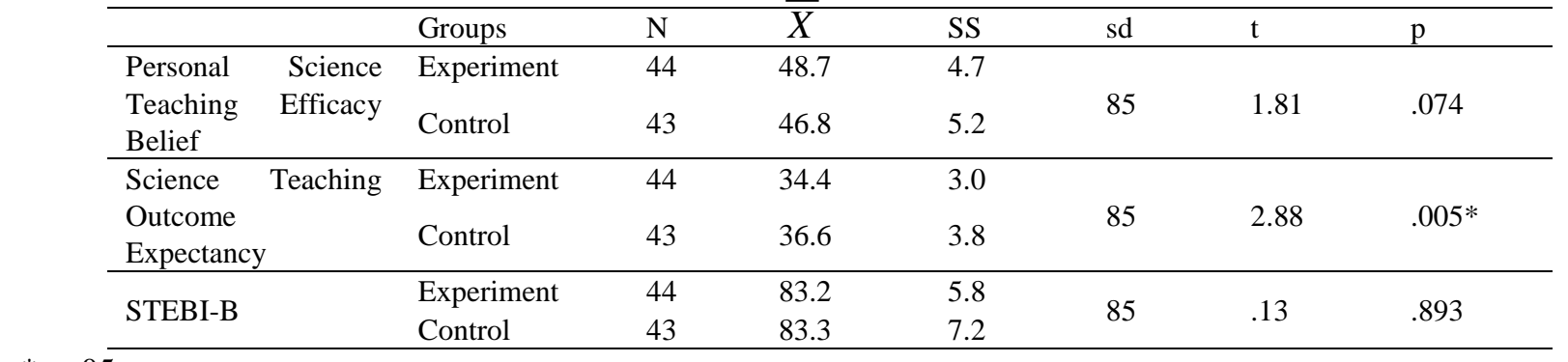

$* \mathrm{p}<.05$

When the post test scores of STEBI-B were evaluated, it was seen that the scores of the experimental and control group science teaching self-efficacy were very close to each other. As a result of the t-test, statistically significant differences 
were not found between the groups' post-test scores related to the overall STEBI $\left[\mathrm{t}_{(85)}=.13, p>.05\right]$. Based on this result, it could be said that metacognitive strategies did not have an effect on prospective teachers' science teaching efficacy perceptions. When the efficacy levels of the STEBI-B factors, Personal Science Teaching Efficacy perceptions of the experimental group were higher than the control group. As a result of the t-test, statistically significant differences were not found between the groups' post-test scores related to the personal Science Teaching Efficacy $\left[\mathrm{t}_{(85)}=1.81, p>.05\right]$. Science Teaching Outcome Expectancy perceptions of the control group were higher than experimental group. According to the t-test result, this difference is statistically significant $[\mathrm{t}(85)=2.88, \mathrm{p}<.05]$.

The data about the STEBI-B obtained from the pre-test and post-test performed in different groups was presented in Table 4.

Table 4. Means, standart deviations and comparisons control and experimental group science teaching efficacy beliefs by pre and post test

\begin{tabular}{|c|c|c|c|c|c|}
\hline \multirow[t]{2}{*}{ Group } & & \multirow{2}{*}{$\begin{array}{l}\mathrm{M}(\mathrm{SD}) \\
\text { Pre Test }\end{array}$} & \multirow{2}{*}{$\begin{array}{l}M(S D) \\
\text { Post Test }\end{array}$} & \multirow[t]{2}{*}{$\mathrm{t}$} & \multirow[t]{2}{*}{$\mathrm{p}$} \\
\hline & & & & & \\
\hline \multirow{2}{*}{$\begin{array}{l}\text { Personal Science Teaching } \\
\text { Efficacy Belief }\end{array}$} & Experiment & $47.3(6.5)$ & $48.7(4.7)$ & 1.83 & .074 \\
\hline & Control & $46.7(5.7)$ & $46.8(5.2)$ & .06 & .951 \\
\hline \multirow{2}{*}{$\begin{array}{l}\text { Science Teaching Outcome } \\
\text { Expectancy }\end{array}$} & Experiment & $34.7(5.1)$ & $34.5(3.0)$ & .323 & .749 \\
\hline & Control & $36.7(5.3)$ & $36.6(3.8)$ & .30 & .764 \\
\hline \multirow{2}{*}{ STEBI-B } & Experiment & $81.9(7.8)$ & $83.2(5.8)$ & 1.114 & .272 \\
\hline & Control & $83.5(7.9)$ & $83.3(7.2)$ & .23 & .816 \\
\hline
\end{tabular}

According to Table 4, the scores of the Personal Science Teaching Efficacy Belief and STEBI-B of the experimental group increased in the post-test. However, this difference was not statistically significant as a result of the t-test. The Science Teaching Outcome Expectancy score of the experiment group did not differ in the post-test. In this factor, the efficacy perceptions of experiment group were close to each other in both tests. When the STEBI-B pre-test and post-test scores of control group were evaluated, it was seen that there was no change in the perceptions of the two factors and the overall scale, and the proficiency levels were same [t(42)=.23, p>.05].

\subsection{Comparison of the Post-Test Scores Related to the Teacher Efficacy Beliefs of the Students in Experiment and Control Groups}

The results of the independent sample t-test, which was conducted to examine whether there was any significant difference between the Teacher Efficacy Beliefs post-test scores of the students in experiment and control groups at the end of the experimental investigation, were given in Table 5.

Table 5. Prospective teachers' TES post-test scores results

\begin{tabular}{|c|c|c|c|c|c|c|c|c|}
\hline & & Gruplar & $\mathrm{N}$ & $X$ & $\mathrm{SS}$ & $\mathrm{sd}$ & $\mathrm{t}$ & $\mathrm{p}$ \\
\hline \multirow{2}{*}{$\begin{array}{ll}\text { Efficacy for } & \text { for } \\
\text { Engagement } & \end{array}$} & \multirow[t]{2}{*}{ Student } & Experiment & 44 & 56.9 & 6.1 & \multirow{2}{*}{85} & \multirow{2}{*}{2.12} & \multirow{2}{*}{$.037 *$} \\
\hline & & Control & 43 & 54.3 & 5.5 & & & \\
\hline \multirow{2}{*}{$\begin{array}{l}\text { Efficacy for } \\
\text { Management }\end{array}$} & \multirow{2}{*}{ Classroom } & Experiment & 44 & 58.8 & 6.8 & \multirow{2}{*}{85} & \multirow{2}{*}{1.76} & \multirow{2}{*}{.081} \\
\hline & & Control & 43 & 56.3 & 6.5 & & & \\
\hline \multirow{2}{*}{$\begin{array}{ll}\text { Efficacy for } \\
\text { Strategies }\end{array}$} & \multirow{2}{*}{ Instructional } & Experiment & 44 & 56.9 & 7.0 & \multirow{2}{*}{85} & \multirow{2}{*}{1.98} & \multirow{2}{*}{$.051 *$} \\
\hline & & Control & 43 & 54.1 & 6.2 & & & \\
\hline \multirow{2}{*}{\multicolumn{2}{|c|}{ TES }} & Experiment & 44 & 172.6 & 18.1 & \multirow{2}{*}{85} & \multirow{2}{*}{2.14} & \multirow{2}{*}{$.035 *$} \\
\hline & & Control & 43 & 164.7 & 16.5 & & & \\
\hline
\end{tabular}

$* \mathrm{p}<.05$

When the post-test scores of TES were evaluated, it was seen that the scores of the experimental group post-test scores were higher than control group. As a result of the t-test, statistically significant differences were found between the groups' post-test scores related to the overall STEBI $\left[\mathrm{t}_{(85)}=2.14, p<.05\right]$. This finding suggests that metacognitive strategies increased teacher self-efficacy perceptions of prospective teachers.

According to Table 5, the self-efficacy beliefs of the prospective teachers in the experimental group for Efficacy for Student Engagement, Efficacy for Classroom Management and Efficacy for Instructional Strategies were higher than the control group. As a result of the t-test, statistically significant differences were found between the groups' post-test scores related to the Efficacy for Student Engagement $[\mathrm{t}(85)=2.12, \mathrm{p}<.05]$ and Efficacy for Instructional Strategies $[\mathrm{t}(85)=1.98, \mathrm{p} \leq .05]$ but statistically significant differences were not found between the groups' post-test scores related to Efficacy for Classroom Management $[\mathrm{t}(85)=1.76, \mathrm{p}>.05]$

The Wilcoxon signed-ranks test was performed to determine whether the difference between the pre-test and post-test 
scores of the TES of the experiment and control group was significant in itself. A Wilcoxon Signed Rank Test indicated that the median post-test scores were statistically significantly higher than the median pre-test scores for TES, $\mathrm{z}=2.27$, $\mathrm{p}<.05$.

A Wilcoxon Signed Rank Test indicated that the median post-test scores were statistically significantly higher than the median pre-test scores for Efficacy for Student Engagement, $\mathrm{z}=2.37, \mathrm{p}<.05$ and Efficacy for Classroom Management, $\mathrm{z}=2.29, \mathrm{p}<.05$. These results suggested that metacognitive strategies increased the self-efficacy perceptions of prospective teachers in the experimental group in Efficacy for Student Engagement and Efficacy for Classroom Management. When the scores of the prospective teachers for Efficacy for Instructional Strategies were examined, it was seen that the Efficacy scores were increased in the post-test. But according to the Wilcoxon Signed Rank Test the median post-test scores were not statistically significantly higher than the median pre-test scores, $\mathrm{z}=1.72, \mathrm{p}>.05$.

When the data of the control group about TES were examined, it was seen that the median post-test scores were not statistically significantly higher than the median pre-test scores, $z=1.044, p>.05$. Also Wilcoxon Signed-Rank Tests indicated that the median post-test scores of Efficacy for Student Engagement ( $\mathrm{z}=.739, \mathrm{p}>.05)$, Efficacy for Classroom Management $(z=.437, p>.05)$, and Efficacy for Instructional Strategies $(z=1.033, p>.05)$ were not statistically higher than the median pre-test scores.

\section{Discussion}

It was concluded as a result of the research that the implementations of experimental program design, where the methods of keeping a journal and questioning were used as the metacognitive strategy, influenced the development of the prospective teachers' metacognitive awareness. After the implementation, the experiment group students' awareness levels of the overall MAI and its subdimensions, knowledge of cognition and regulation of cognition significantly enhanced when compared to the pre-test. This finding is parallel with the relevant literature (Abd-El-Khalick \& Akerson, 2009; Çakır, 2011; Erskine, 2009; Foster, 1989; Kincannon et al., 1999; Mevarech \& Amrany, 2008; Peters \& Kitsantas, 2010; Takallou, 2011; Yıldız, 2008). In the study conducted by Abd-El-Khalick \& Akerson, (2009) to research the effect of the three metacognitive strategies on the opinion of the prospective elementary teachers related to the nature of science, the awareness of the prospective teachers in the experiment group, where the metacognitive strategy was used, the dimensions of cognition knowledge and cognition regulation both differed substantially compared to the pre-test and their post-test scores were significantly different from those of the control group. Similarly, Erskine (2009) taught the first-year university students metacognitive skills and strategies. Besides, the students were asked to think reflectively about the metacognitive skills and strategies every week. At the end of the semester, significant differences appeared between the metacognitive awareness of the group taught about the metacognitive skills and strategies, and the control group, which did not receive metacognitive instruction. Another similar result was obtained from the research conducted by Peters and Kitsantas (2010). These researchers investigated the effect of the course 'nature of science', which is discussed with metacognitive directives in the eighth grade, on the students' knowledge, metacognition and pre-regulation competency related to nature of science. The research findings revealed that the nature of science knowledge and metacognition of the students in the experiment group increased at the end of the experimental investigation presenting a significant difference compared to the control group. In Foster's (1989) study, metacognition scores of the students in the experimental group, which consisted of fifth and eighth grade students receiving metacognitive education, increased in the last interview. Examining the effect of metacognitive strategy teaching on the reading comprehension and metacognitive awareness, Takallou (2011) found that metacognitive teaching increased the metacognitive awareness of the experiment groups.

At the end of the experimental study, there was no significant difference between the Science Teaching Efficacy Beliefs and Personal Science Teaching Efficacy Beliefs of the experimental group and the control group students. Metacognitive strategies, asking questions and keeping diaries, did not affect the experimental group students' Science Teaching Efficacy Beliefs and Personal Science Teaching Efficacy Beliefs. But in the post-test the control group's Science Teaching Outcome Expectancy Beliefs scores were higher than those in the experimental group and this difference was statistically significant. In Küçükyılmaz and Duban (2006)'s research, primary teacher candidates stated that they should have competences such as strong field knowledge, ability to reduce the existing knowledge to the student level, experiment and make it, and use the appropriate teaching methods and technology in order to be qualified in science education. When they think of all these details, some believe highly in themselves, others live in an intense sense of disability (Küçükyılmaz \& Duban, 2006). The results in Table 3 regarding the science teaching outcome expectancy, which explain the beliefs that teachers can influence student learning, can be explained by this belief of Küçükyılmaz and Duban (2006). Because the teacher candidates in the experiment group tend to think metacognitively, they may have responded more deeply to the question of the Science Teaching Outcome Expectancy Beliefs. On the contrary, prospective teachers in the control group may not be realistic without considering all the details and assessing self-efficacy perceptions. 
At the end of the experimental period, Science Teaching Efficacy Beliefs and Personal Science Teaching Efficacy Beliefs of experimental group were increased but this increase was not statistically significant than pre-test scores. At the end of the study, the efficacy perceptions of the Science Teaching Outcome Expectancy of the prospective teachers in the experimental group did not change. This indicates that the metacognitive strategies applied in the experimental group positively affect only Personal Science Teaching Efficacy Beliefs of the prospective teachers. On the other hand, the Science Teaching Efficacy Beliefs of the students in the control group did not change. The research results about the effects of Science and Technology Teaching Course on prospective primary school teachers' science teaching self-efficacy beliefs, conducted by Bursal (2007), support these findings. In this research, the effect of science teaching course on science teachers' self-efficacy beliefs in America and Turkey was examined, while there was a significant increase in science teaching self-efficacy perception of American students, there was a decrease in science teaching self-efficacy perceptions of Turkish students. According to Bursal (2007), the lack of school experience and the inability to observe the classroom teacher, the negative attitude towards classroom teaching, the lack of positive classroom support to ensure their competence in science concepts has led to the failure of the science teaching course. Bursal (2007) suggested that this course should include professional experience as well as the activities in the science teaching course to increase the science teaching self-efficacy of the prospective classroom teachers. Similarly, Smolleck and Mongan (2011) have observed that well-planned science methods and teaching practice experience have improved the science teaching self-efficacy of prospective classroom teachers.

At the end of the experimental study, there was a significant difference between the prospective teachers' teacher self-efficacy beliefs of the experimental group and control group. This difference has been found in Efficacy for Student Engagement, Efficacy for Instructional Strategies and the TES. This suggests that metacognitive strategies increased prospective teachers' teacher self-efficacy beliefs about student engagement and instructional strategies. Metacognitive strategies increased experimental group students' Efficacy for Student Engagement, Efficacy for Classroom Management and all over TES significantly with pre-test. Asking questions and keeping diaries had an impact on prospective teachers' teacher self-efficacy beliefs. The TES scores of the control group in the post-test did not increase significantly compared with the pre-test.

These results are consistent with the results of Baykara (2011). Baykara (2011) found a significant relationship between prospective teachers' teacher self efficacy beliefs and their metacognitive learning strategies.

Similarly, Cain (2001) found a positive relationship between metacognition and self-efficacy in his research. According to Cain (2001), high level metacognition is accompanied by high self-efficacy. Coutinho (2008) also found a significant relationship between college students' self-efficacy beliefs and their metacognitive awareness. According to Coutinho (2008), the most successful students have strong metacognitive skills to observe and evaluate their performance and are fully convinced of their abilities to perform the task successfully. The findings of Hongyan, Guixia and Huiqing (2009) support this finding. In this study, learning strategies, especially metacognitive learning strategies were introduced to the freshman and they were guided for planning, monitoring and evaluating their learning. As a result of the research, metacognition strategy has been found to improve students' self-efficacy beliefs. Jacobson and Viko (2010) found that the metacognitive self-assessment strategy improved secondary school students' success and self-efficacy in chemistry. Bouffard-Bouchard, Parent and Larivee (1991) have achieved similar results in their research. According to these researchers, students with strong self-efficacy occupy more metacognitive skills and receive better grades than students with low self-efficacy. Similarly, Kanfer and Ackerman (1989) state that individuals who have a strong self-efficacy belief use metacognitive strategies when performing a task, and that these individuals perform their duties better than individuals with weak self-efficacy belief. Landine (1994) found a positive relationship between metacognition and self-efficacy. The data on the prospective teachers' responses about the TES are similar to those of Rampp and Guffey (1999). Rampp and Guffey (1999) conducted an experimental study with 25 freshman at Arkansas University. In this study, it was understood that the students in the experimental group receiving metacognitive instruction had a high level of academic self-efficacy at the end of the experimental period. According to the researchers, metacognitive instruction has important effects on students' self-efficacy beliefs. The results of the study conducted by Hongyan (2009) and investigating the effects of metacognitive strategies on university students' English self-efficacy beliefs support the results of this research. This research and the similar researches' results mentioned above show that metacognitive strategies have improved self-efficacy. Thus, the use of metacognitive strategies in both pre-service and in-service training of teachers can increase their professional self-efficacy and also job satisfaction.

\section{Recommendations}

Metacognitive strategies increased the metacognitive awareness of the prospective teachers in this research. Teachers, who have a high level of awareness level, can solve their problems that they may encounter in their professional lives more easily. In this sense, it is important to determine the teachers' metacognition and perception about their professional competency and provide the appropriate education before the service. Metacognitive skills can be 
developed with teaching. Prospective teachers, who learn the metacognitive strategies during the pre-service education, will also apply these learning strategies in their own classes. Incorporating such strategies and methods into the teacher educating programs and their inclusion in the scope of the courses Teaching Principles and Methods or Special Teaching Methods will make the teacher education more efficient. Considering the results of the research (Narang \& Saini, 2013; Özsoy \& Ataman, 2009; Polat \& Uslu, 2012), which highlighted that metacognitive skill increased the academic success of the students, it is important to teach the students of the other faculties and academies, even high school and primary education students not to limit the metacognitive education only with teacher education, but to train more qualified university graduates. Therefore, it is necessary to add the metacognition in the teaching curriculums at university and other teaching stages and to give importance to appropriate implementations in teaching processes.

It was realized as a result of the research that keeping a journal, which was used as a metacognitive strategy, influenced the metacognitive awareness of the students positively. For this reason, students must be encouraged in teacher education programs, especially in professional courses regarding teaching to keep a journal for letting them think about their opinions and learning processes.

Metacognitive strategies have increased prospective teachers' self-efficacy beliefs in this study. Self-efficacy perception is one of the important factors determining the success of a person. High self-efficacy perceptions of prospective teachers will affect the quality of the graduated teacher and the quality of the education that these teachers will teach. For this reason, teacher education programs should be organized in order to increase the metacognitive knowledge and skills of the prospective teachers to provide more qualified education to them.

Teachers are models for students in exhibiting metacognitive behaviors as well as cognitive behaviors. Therefore, a teacher who expects the metacognitive skills to develop in the classroom environment must primarily have these skills himself/herself. When considered from this aspect, significant responsibilities fall to the academicians who work in institutions training teachers. Courses or seminars must be organized so that these academicians can be aware of the importance of metacognition and metacognitive strategies.

The number of the studies, in which metacognitive strategies were taught to prospective teachers and the results of this teaching were discussed, were very few in Turkey during the period when this study was conducted. Therefore, studies can be conducted in different sampling groups with regard to the usage of metacognitive strategies in teacher education. The effect of the metacognitive strategies on various variables such as success, motivation, pre-regulation skill and exam anxiety can be investigated in these studies.

\section{Acknowledgements}

This study and investigation has been endorsed by Cumhuriyet University CÜBAP Chairmanship with Project No EGT-024. Sincerely thank CÜBAP Chairmanship for their endorsement.

\section{References}

Abd-El-Khalick, F., \& Akerson, V. (2009). The influence of metacognitive training on preservice elementary teachers' conceptions of nature of science. International Journal of Science Education, 31(16), 2161-2184. https://doi.org/10.1080/09500690802563324

Akbaş, A., \& Çelikkaleli, Ö. (2006). Examination of science teachers' self-efficacy beliefs of classroom teacher candidates according to gender, type of education and universities. Mersin University Journal of Education, 2(1), 98-110.

Akın, A., Abacı, R., \& Çetin, B. (2007). The validity and reliability of the Turkish version of the metacognitive awareness inventory. Educational Sciences: Theory \&Practice, 7(2), 657-680.

Bandura A. (1995). Self- efficacy in changing societies. New York: Cambridge University Press. https://doi.org/10.1017/CBO9780511527692

Bandura, A. (1982). Self efficacy mechanism in human agency. American Psychologist, 37(2), 122-147. https://doi.org/10.1037/0003-066X.37.2.122

Bandura, A. (1997). Self-efficacy in changing societies. A. Bandura (Ed.) Exercise of personal and collective efficacy in changing societies, New York: Cambridge University Pres, pp. 1-45.

Baykara, K. (2011). A study on "teacher efficacy perceptions" and "metacognitive Learning strategies" of prospective teachers. Hacettepe University Journal of Education, 40, 80-92.

Bouffard-Bouchard, T., Parent, S., \& Larivee, S. (1991). Influence of self efficacy on self-regulation and performance among junior and senior high school age students. International Journal of Behavioral Development, 14(2), 153-164. https://doi.org/10.1177/016502549101400203 
Bursal, M. (2007). The impact of science methods courses on preservice elementary teachers' science teaching self-efficacy beliefs: Case studies from Turkey and the United States. Doctoral Thesis. University of Minnesota, Minnesota, United States.

Cain, R. E. (2001). The relationships of metacognition, self efficacy and educational and/or flight experince to situation awareness in aviation students. A Dissertation Presented to tho Faculty of the Graduate School University of Missouri, Columbia.

Çakır, B. (2011). Pre-service science teachers' metacognition in a science laboratory course with metacognitively oriented learning environment. Master's thesis, Middle East Technical University, Ankara.

Çapa, Y., Çakıroğlu, J., \& Sarıkaya, H. (2005). The development and validation of a Turkish version of the teachers' sense of efficacy scale, Education and Science, 30(137), 74-81.

Costa, A. L. (1984). Mediating the metacognitive. Educational Leadership, 42(3), 57-62.

Coutinho, S. (2008). Self-efficacy, metacognition, and performance. North American Journal of Psychology, 10(1), $165-172$.

Darling-Hammond, L., Austin, K., Cheung, M., \& Martin, D. (2003). Thinking about thinking: Metacognition. Retrieved from http://www.learner.org/courses/ learningclassroom/support/09_metacog.pdf>

Erskine, D. L. (2009). Effect of prompted reflection and metacognitive skill instruction on university freshmen's use of metacognition. Doctoral dissertation, Brigham Young University, Brigham.

Flavell. J. H. (1985). Cognitive development (2nd ed.). Englewood Cliffs, NJ: Prentice- Hall.

Foster, M. L. R. (1989). The effects of metacognitive training on fifth and eighth graders' reading comprehension and metacognitive awareness. (Unpublished doctoral dissertation), University of Nebraska, Lincoln, Nebraska.

Hacker, D. J. (1998). Definitions and empirical foundations. In: D. J. Hacker., J. Dunlosky and A.C. Graesser (Eds.), Metacognition in educational theory and practice (pp. 1-23). Mahwah, NJ: Lawrence Erlbaum Associates.

Hongyan, Z. (2009). The research of metacognitive theorys training on english self-efficacy. International Conference on Computer Technology and Development, 2, Kota Kinabalu, Malaysia. https://doi.org/10.1109/ICCTD.2009.95

Hongyan, Z., Guixia, N., \& Huiqing, T. (2009). The research of metacognitive theories training on English self-efficacy. Paper presented in International Conference on Computer Technology and Development. https://doi.org/10.1109/ICCTD.2009.95

Jacobs, J. E., \& Paris, S. G. (1987). Children's metacognition about reading: Issues in definition, measurement, and instruction. Educational Psychologist, 22(3-4), 255-278. https://doi.org/10.1080/00461520.1987.9653052

Jacobson, B. N., \& Viko, B. (2010). Effect of instruction in metacognitive self-assessment strategy on chemistry self-efficacy and achievement of senior secondary school students in rivers state, Nigeria. Academic Leadership. The Online Journal. 8(4). Web: http://www.academicleadership.org/article/effect-of-instruction-in-metacognitive-self-assessment-strategy-on-che mistry-self-efficacy-and-achievement-of-senior-secondary-school-students-in-rivers-state-nigeria

Kanfer, R., \& Ackerman, P. L. (1989). Motivation and cognitive abilities: An integrative/aptitude-treatment interaction approach to skill acquisition. Journal of Applied Psychology, 74, 657-690. https://doi.org/10.1037/0021-9010.74.4.657

Kapa, E. (2001). A metacognitive support during the process of problem solving in a computerized environment. Educational Studies in Mathematics. https://doi.org/10.1023/A:1015124013119

Kincannon, J., Gleber, C., \& Kim, J. (1999). The effects of metacognitive training on performance and use of metacognitive skills in self-directed learning situations. Proceedings of Selected Research and Development Papers Presented at the National Convention of the Association for Educational Communications and Technology .

Kiremit, H. Ö., \& Gökler, İ. (2010). Comparison of preservice science teachers' self-efficacy beliefs in teaching biology. Pamukkale University Journal of Education, 27, 41-54.

Küçükyılmaz, A. \& Duban, N. (2006). The opinions of primary teacher candidates on taking measures to increase science teaching self-efficacy beliefs. Yüzüncü Yıl University Journal of Education, III(II), 1-23.

Landine, J. R. (1994). Relationship between metacognitive approaches, and motivation, locus of control, self efficacy, and academic achievement. A Thesis Submitted In Partial Fulfilment of the Requirements For The Degree Of Master in Education. The University of New Brunswick. 
Mevarech, Z. R., \& Amrany, C. (2008). Immediate and delayed effects of meta-cognitive instruction on regulation of cognition and mathematics achievement. Metacognition and Learning. https://doi.org/10.1007/s11409-008-9023-3

Narang, D., \& Saini, S. (2013). Metacognition and academic performance of rural adolescents. Studies on Home and Community Science, 7(3), 167-175.

Noushad, P. P. (2008). Cognitions about cognitions: The theory of metacognition. Retrieved from http://www.eric.ed.gov/PDFS/ED502151.pdf

Öz, H. (2005). Metacognition in foreign/second language learning and teaching. Hacettepe University Journal of Education, 29, 147-156.

Özkan, Ö., Tekkaya, C., \& Çakıroğlu, J. (2002). Fen bilgisi aday öğretmenlerinin fen kavramlarını anlama düzeyleri, fen ögretimine yönelik tutum ve öz-yeterlik inançlart. V. Ulusal Fen Bilimler ve Matematik Eğitimi Kongresi, ODTÜ- Ankara.

Özsoy, G., \& Ataman, A. (2009). The effect of metacognitive strategy training on mathematical problem solving achievement. International Electronic Journal of Elementary Education, 1(2), 67-82.

Peters, E., \& Kitsantas, A. (2010). The effect of nature of science metacognitive prompts on science students' content and nature of science knowledge, metacognition, and self-regulatory efficacy. School Science and Mathematics. https://doi.org/10.1111/j.1949-8594.2010.00050.x

Polat, S., \& Uslu, M. (2012). Fen ve teknoloji dersinde üstbiliş stratejilerine dayalı öğretim uygulamasının 5. sınıf öğrencilerinin erişilerine etkisi. Uş̧ak Üniversitesi Sosyal Bilimler Dergisi, 5(3), 28-43. https://doi.org/10.12780/UUSBD122

Rampp, L. C., \& Guffey, J. S. (1999). The impact of metacognition training on academic self-efficacy of selected underachieving college students. Report. Web:

http://www.eric.ed.gov/ERICDocs/data/ericdocs2sq1/content_storage_01/0000019b/80/17/a9/b1.pdf

Riggs, I. M., \& Enochs, L. G. (1989). Toward the development of an elementary teacher's science teaching efficacy belief instrument. Paper Presented At The Annual Meeting of the National Association for Research in Science Teching, 62nd ,San Francisco, CA.

Schraw, G., \& Dennison, R. S. (1994). Assessing metacognitive awareness. Contemporary Educational Psychology, 19 , 460-475. https://doi.org/10.1006/ceps.1994.1033

Smolleck, L. A., \& Mongan, A. M. (2011). Changes in preservice teachers' self-efficacy: from science methods to student teaching. Journal of Educational and Developmental Psychology, 1(1), 133-145. https://doi.org/10.5539/jedp.v1n1p133

Steinbach, J. C. (2008). The effect of metacognitive strategy instruction on writing. (Unpublished doctoral dissertation ), University of Kentucky, Lexington, Kentucky.

Takallou, F. (2011). The effect of metacognitive strategy instruction on efl learners' reading comprehension performance and metacognitive awareness. Asian EFL Journal, 13(1), 272-300.

Tschannen-Moran, M., \& Hoy, W. K. (1998). Teacher efficacy: capturing an elusive construct. Teaching and Teacher Education, 17(2001), 783-805.

Tschannen-Moran, M., \& Hoy, W. K. (1998). Teacher efficacy: Its meaning and measure, Review of Educational Research, 68(2), 202-248. https://doi.org/10.3102/00346543068002202

Williams, J. P., \& Atkins, J. G. (2009). The role of metacognition in teaching reading comprehension to primary students. In: H. Douglas, J. Dunlosky, A. C. Grasser (Eds.), Handbook of metacognition in education (pp.26-43). UK: J. Routledge.

Yıldız, E. (2008). The effects of metacognition during the instruction based on conceptual change used with 5e model: an application regarding the force and motion subject in the 7th grade. (Unpublished doctoral dissertation), Dokuz Eylül University, İzmir.

\section{Copyrights}

Copyright for this article is retained by the author(s), with first publication rights granted to the journal.

This is an open-access article distributed under the terms and conditions of the Creative Commons Attribution license which permits unrestricted use, distribution, and reproduction in any medium, provided the original work is properly cited. 